Research Article

\title{
A Study to Assess the Level of Expressed Satisfaction Related to Abortion Associated Services among Women Who have Undergone Abortion
}

\author{
Alice Moirangthem', Manju Chhugani', Gifty Bijoy ${ }^{3}$
}

${ }^{1}$ M.Sc.Nursing (Obstetrical and Gynecological Nursing) 2nd Year, ${ }^{2}$ Dean SNSAH, ${ }^{3}$ Tutor, Rufaida College of Nursing, Jamia Hamdard, New Delhi.

DOI: https://doi.org/10.24321/2455.9318.202011

\section{I $\quad \mathbf{N} \quad \mathbf{F} \quad \mathbf{O}$}

\section{Corresponding Author:}

Alice Moirangthem, Rufaida College of Nursing, Jamia Hamdard, New Delhi.

E-mail Id:

alicemoirangcha999@gmail.com

Orcid Id:

https://orcid.org/0000-0002-4882-686X

How to cite this article:

Moirangthem A, Chhugani M, Bijoy G. A Study to Assess the Level of Expressed Satisfaction Related to Abortion Associated Services among Women Who have Undergone Abortion. Int J Nurs Midwif Res 2020; 7(2): 3-10.

Date of Submission: 2020-07-18

Date of Acceptance: 2020-12-01

\section{$\begin{array}{llllllll}\mathbf{A} & \mathbf{B} & \mathbf{S} & \mathbf{T} & \mathbf{R} & \mathbf{A} & \mathbf{C} & \mathbf{T}\end{array}$}

Introduction: In India, abortion is permissible under the MTP Act, and is legalized in both the public and private sectors.

Objective: The study aimed to assess the level of expressed satisfaction related to abortion associated services among women who have undergone abortion in selected hospitals of Manipur.

Materials and Methods: Quantitative (non-experimental) approach with descriptive research design was used. 50 women of reproductive age group, attending the hospitals to undergo abortion in selected hospitals of Manipur during the study period were included using purposive sampling technique. Structured interview schedule with 5 point Likert Scale was used to assess the level of expressed satisfaction related to abortion associated services. Data was analyzed using descriptive and inferential statistics.

Result: Out of 50 women interviewed, almost half of the subjects (46\%) were in the age group of 25-30 years, more than half of the subjects $(62 \%)$ had primary educational level, more than half of the subjects (68\%) were housewife and maximum number of the subjects (76\%) was from rural community. The study results depicted that majority of the women (48\%) were satisfied with abortion associated services, $42 \%$ were within the neutral range and $10 \%$ of the subjects expressed the satisfaction level as dissatisfied. The results also concluded that, women were most satisfied during clinical assessment and least satisfied during post-abortion care. And there is no association between the level of expressed satisfaction related to abortion associated services and selected demographic variables of the woman.

Conclusion: Counseling and supporting the woman who have undergone abortion could have great impact on the improvement of post-abortion care.

Keywords: Abortion, Level of Expressed Satisfaction, Women 


\section{Introduction}

Abortion is the expulsion or extraction of fetus from the uterus' ${ }^{1}$, may occur spontaneously or purposefully in which they are termed as miscarriage and induced abortion respectively. Induced abortions may be performed for various causes' like- preservation of the physical and psychological well-being of the mother, prevention of pregnancy from rape or incest, prevention of birth of a child with serious deformity and prevention of birth for social and economic reasons.

Susheela S, Fatima J, Elena P., evaluated national abortion occurrence through three separate segments: abortions(medication and surgical) in facilities(counting private sector, public sector, and non-governmental organization); medication abortion outside facilities; and abortions outside of facilities and with methods other than prescription. The study findings concluded that 15.6 million abortions (14.1 million-17.3 million) occurred in India in 2015.The abortion rate was 47.0 million abortions (42.2-52.1) per 1000 women aged $15-49$ years. 3.4 million abortions (22\%)were acquired in health facilities, 11.5 million (73\%) abortions were prescribed abortion done outside of health facilities, and 0.8 million (5\%) abortions were done outside of health facilities utilising strategies other than medication abortion. By and large, 12.7million (8\%) abortions were medical abortions, 2.2 million (14\%) abortions were surgical, and 0.8 million (5\%) abortions were done through other techniques that were presumably perilous. It was additionally evaluated that 48.1 million pregnancies, at a pace of 144.7 pregnancies per 1000 women aged 15-49 year occur where abortion represented for $33 \%$ of all pregnancies, and about portion of pregnancies were unintended. ${ }^{2}$

Despite of the increasing trend in the demand of abortion services, its accessibility is also an important component to deal with abortion services effectively. In a study conducted by Sushanta K., on access to safe abortion administrations and suggestions for conducting change correspondence uncovered those poor ladies who had never attended school and with constrained introduction on communication depended on community health workers, family and friends for health information. Woman with adequate source and information on abortion notified that abortion services are accessible and were bound to have positive attitude towards abortion. Woman with revealed presentation to abortion messages have favorable attitude towards abortion with the conclusion that increasing community awareness and information on abortion with improvement of local safe services can expand potential access to services. ${ }^{3}$ According to HMIS reports, the total number of induced abortions that took place in India from 2013-2016 shows an increasing trend with increased demand of abortion and to make these services reach an optimum and maximum level of satisfaction, the health care team roles and responsibilities are elevated. ${ }^{4}$

Bekalu MC, Dame AA, Tamirie A., did a study to evaluate satisfaction with abortion care. The study delineated that women's satisfaction with comprehensive abortion care consists of five major factors- positive interpersonal communication with care-receiver, pleasantness of physical environment, offering enough information related to the procedure, securing client's privacy during treatment and counseling and technical quality of the providers with the conclusion that evaluating abortion care satisfaction can advance service qualities. ${ }^{5}$ Studies have shown that poor service quality results in low acceptability of legal abortion which can result in drastic changes on abortion related morbidity and mortality. ${ }^{6}$ In a study directed by Philippa T., to consider the drawn out psycho-social impacts of abortion and their responses, jumped on to the fact that the women experienced fluctuating reactions to the abortion that stayed progressing for quite a long time; others were sure or impartial quickly yet experienced shifting negative reactions some time later. A few had positive encounters later on and felt it was the correct choice at that point, however they felt sad and remorse to some extent. ${ }^{7}$ Many studies have been conducted on abortion and its services, but the level of satisfaction expressed by the woman is not given due significance and always been an ignored area. With this extensive review of existing literature, the researcher felt the need for exploring the level of expressed satisfaction of the woman towards abortion associated services. So the present study was conducted with the following objectives:

- To assess the level of expressed satisfaction related to abortion associated services among women who have undergone abortion in selected hospitals of Manipur.

- To find out the association between the levels of expressed satisfaction related to abortion associated services with selected demographic variables of the woman.

- To develop and disseminate IEC materials on postabortion care of women.

\section{Materials and Methods}

Quantitative approach with non-experimental descriptive design was used for the study. Structured interviews were scheduled to collect the data regarding expressed satisfaction towards abortion associated services. The study was conducted in 5 health care facilities of Manipur during the period from $26^{\text {th }}$ October to $12^{\text {th }}$ November, 2019 at Ningthoukhong PHC, CHCs of Moirang and Nambol and district hospitals of Bishnupur and Churachandpur. 50 women of reproductive age group who had undergone abortion during the study period were selected using 
purposive sampling technique. Attrition and sample contamination was prevented during the data collection. The tool for data collection comprised of two sections: Section A includes demographic characteristics of the subject and Section B consisting of 5 point Likert scale to assess the level of expressed satisfaction related to abortion associated services. It consists of 6 components and 26 items. The tools were developed after extensive review by 7 experts from the field of obstetrics and gynecology. The IEC materials to be disseminated were given under the guidance from IPAS, USAID and were developed in the form of pamphlets. The reliability of the tool was established using Cronbach alpha and with $r=0.9$, the tool was proved to be reliable. Scoring was done by dividing the scores into different categories as reflected in Table 1and Table 2.

Table I.Points of scale and scoring system

\begin{tabular}{|c|c|c|}
\hline S. No. & Points of scale & Score \\
\hline 1. & Highly satisfied & 5 \\
\hline 2. & Satisfied & 4 \\
\hline 3. & Neutral & 3 \\
\hline 4. & Dissatisfied & 2 \\
\hline 5. & Highly dissatisfied & 1 \\
\hline
\end{tabular}

Table 2.Categorisation of the level of expressed satisfaction according to range of scores

\begin{tabular}{|c|c|c|c|}
\hline $\begin{array}{c}\text { S. } \\
\text { No. }\end{array}$ & Category & $\begin{array}{c}\text { Range of } \\
\text { score }\end{array}$ & $\begin{array}{c}\text { Percentage } \\
\text { (\%) }\end{array}$ \\
\hline 1. & Highly satisfied & $110-130$ & 20 \\
\hline 2. & Satisfied & $89-109$ & 20 \\
\hline 3. & Neutral & $68-88$ & 20 \\
\hline 4. & Dissatisfied & $47-67$ & 20 \\
\hline 5. & Highly dissatisfied & $26-46$ & 20 \\
\hline
\end{tabular}

After obtaining ethical permission from IEC and permission from the selected hospitals administrative authority, informed consent was taken from the subjects with full autonomy to participate in the research and withdraw anytime. The tools were administered on the selected sample. Data was analyzed using descriptive and inferential statistics.

\section{Result}

SECTION I: Findings on description of the demographic characteristics of the woman:

The study findings depicted that out of 50 women, almost half of the subjects $23(46 \%)$ were in the age group of $25-30$ years, more than half of the subjects $31(62 \%)$ had primary level education, more than half of the subjects 31 (62\%) belonged to Hindu religion, more than half of the subjects $33(66 \%)$ have conceived twice, maximum number of the subjects $38(76 \%)$ were from rural community, and maximum number of the subjects $39(78 \%)$ had undergone D/E or D/C.

Table 3 and figure 1, show the frequency and percentage distribution of woman as per their demographic characteristics.

Table 3.Frequency and percentage distribution of woman as per their demographic characteristics

\begin{tabular}{|c|c|c|c|}
\hline $\begin{array}{l}\text { S. } \\
\text { No. }\end{array}$ & Demographic Profile & $\begin{array}{l}\text { Frequency } \\
\text { (f) }\end{array}$ & \begin{tabular}{|c|} 
Percentage \\
(\%)
\end{tabular} \\
\hline \multirow[t]{5}{*}{1.} & Age (in years) & & \\
\hline & $18-24$ & 8 & 16 \\
\hline & $25-30$ & 23 & 46 \\
\hline & $31-36$ & 15 & 30 \\
\hline & Above 36 years & 4 & 8 \\
\hline \multirow[t]{6}{*}{2.} & Educational level & & \\
\hline & Illiterate & 5 & 10 \\
\hline & Primary school & 31 & 62 \\
\hline & Higher secondary & 12 & 24 \\
\hline & Graduate & 2 & 4 \\
\hline & Post-graduate & 0 & 0 \\
\hline \multirow[t]{5}{*}{3.} & Religion & & \\
\hline & Hindu & 31 & 62 \\
\hline & Christian & 19 & 38 \\
\hline & Muslim & 0 & 0 \\
\hline & Any other & 0 & 0 \\
\hline \multirow[t]{4}{*}{4.} & Number of conception & & \\
\hline & 1 & 4 & 8 \\
\hline & 2 & 33 & 66 \\
\hline & More than 3. & 13 & 26 \\
\hline \multirow[t]{5}{*}{5.} & Occupation & & \\
\hline & Housewife & 34 & 68 \\
\hline & Daily wager & 13 & 26 \\
\hline & Service (govt./ private) & 2 & 4 \\
\hline & Self-employed & 1 & 2 \\
\hline \multirow[t]{3}{*}{6.} & Type of family & & \\
\hline & Nuclear & 21 & 42 \\
\hline & Joint & 29 & 58 \\
\hline \multirow[t]{4}{*}{7.} & $\begin{array}{l}\text { Family monthly } \\
\text { income }\end{array}$ & & \\
\hline & Below Rs.5000 & 1 & 2 \\
\hline & Rs. $5001-10000$ & 30 & 60 \\
\hline & Rs. $10001-15000$ & 19 & 38 \\
\hline
\end{tabular}




\begin{tabular}{|c|c|c|c|}
\hline & Above Rs. 15000 & 0 & 0 \\
\hline 8. & Type of community & & \\
\hline & Rural & 38 & 38 \\
\hline & Urban & 12 & 12 \\
\hline 9. & Method of abortion & 1 & 2 \\
\hline & $\begin{array}{c}\text { MMA(Medical Method } \\
\text { of Abortion) }\end{array}$ & 10 & 20 \\
\hline & $\begin{array}{c}\text { Electric/ Manual } \\
\text { Vacuum Aspiration }\end{array}$ & 39 & 78 \\
\hline & D/E or D/C & 0 & 0 \\
\hline & Mixed Method & & \\
\hline
\end{tabular}

the satisfied range, 21 (42\%) were within the neutral range, and minimum number of the subjects $5(10 \%)$ expressed the satisfaction level within the dissatisfied range.
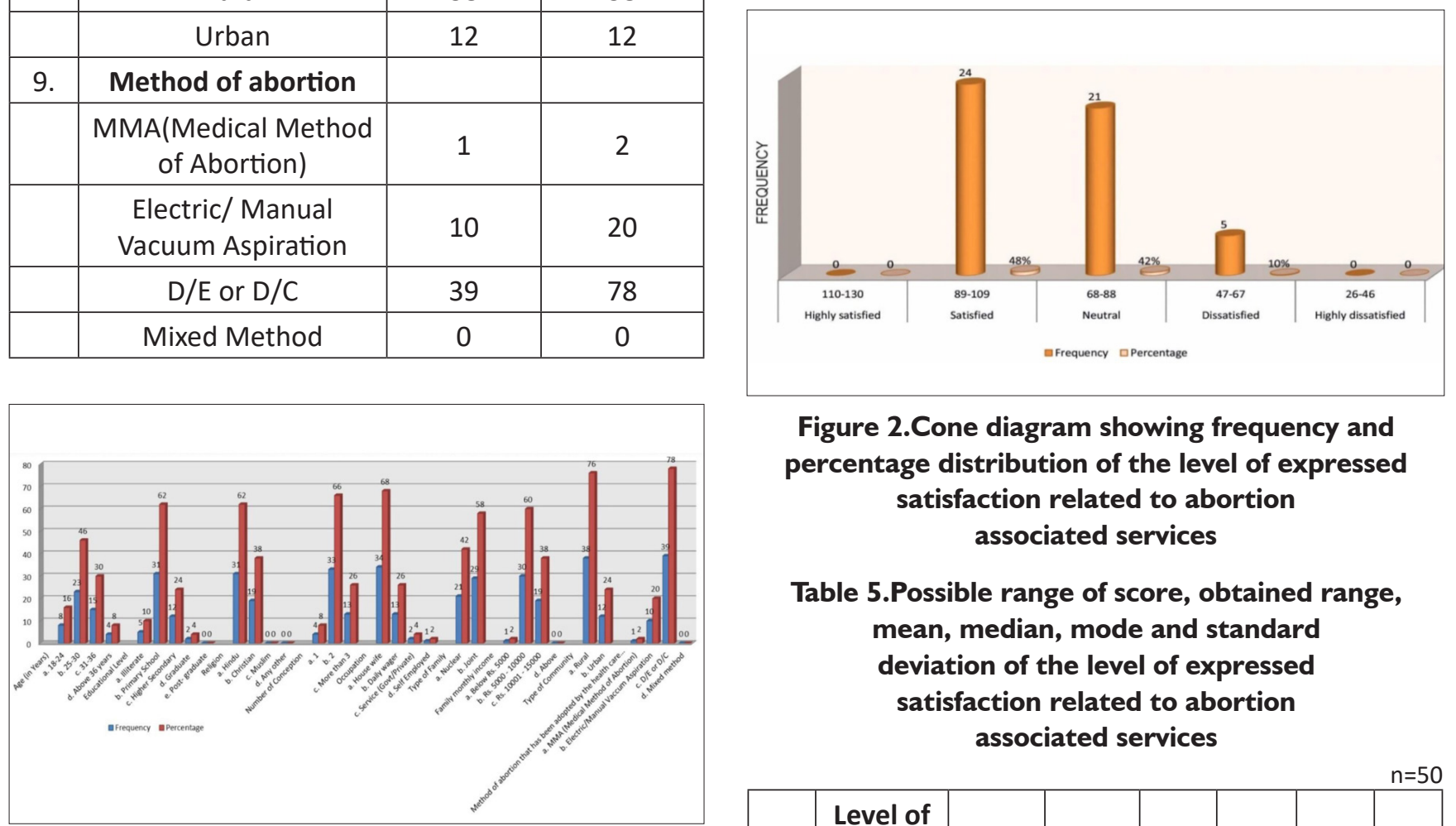

Figure I.Bar diagram showing frequency and percentage distribution of woman as per their demographic characteristics

Section II: Findings related to level of expressed satisfaction with abortion associated services among women who have undergone abortion

Table 4.Frequency and percentage distribution of the level of expressed satisfaction related to abortion associated services

\begin{tabular}{|c|c|c|c|c|}
\hline $\begin{array}{c}\text { S. } \\
\text { No. }\end{array}$ & $\begin{array}{c}\text { Level of } \\
\text { expressed } \\
\text { satisfaction }\end{array}$ & $\begin{array}{c}\text { Possible } \\
\text { range of } \\
\text { score }\end{array}$ & Frequency & $\begin{array}{c}\mathrm{Percentage} \\
\text { (\%) }\end{array}$ \\
\hline 1. & $\begin{array}{c}\text { Highly } \\
\text { satisfied }\end{array}$ & $110-130$ & 0 & 0 \\
\hline 2. & Satisfied & $89-109$ & 24 & 48 \\
\hline 3. & Neutral & $68-88$ & 21 & 42 \\
\hline 4. & Dissatisfied & $47-67$ & 5 & 10 \\
\hline 5. & $\begin{array}{c}\text { Highly } \\
\text { dissatisfied }\end{array}$ & $26-46$ & 0 & 0 \\
\hline
\end{tabular}

The data in table 4 and figure 2 , show that almost half of the subjects 24 (48\%) expressed their satisfaction level within

Figure 2.Cone diagram showing frequency and percentage distribution of the level of expressed satisfaction related to abortion associated services

Table 5.Possible range of score, obtained range, mean, median, mode and standard deviation of the level of expressed satisfaction related to abortion associated services

\begin{tabular}{|c|c|c|c|c|c|c|c|}
\hline & $\begin{array}{c}\text { Level of } \\
\text { expr- } \\
\text { essed } \\
\text { satisf- } \\
\text { action } \\
\text { related } \\
\text { to } \\
\text { No. } \\
\text { abortion } \\
\text { asso- } \\
\text { ciated } \\
\text { services }\end{array}$ & $\begin{array}{c}\text { Pos- } \\
\text { sible } \\
\text { range } \\
\text { of } \\
\text { score }\end{array}$ & $\begin{array}{c}\text { Obta- } \\
\text { ined } \\
\text { range }\end{array}$ & $\begin{array}{c}\text { Me- } \\
\text { an }\end{array}$ & $\begin{array}{c}\text { Me- } \\
\text { dian }\end{array}$ & $\begin{array}{c}\text { Mo- } \\
\text { de }\end{array}$ & S.D \\
\hline 1. & $\begin{array}{c}\text { Satisfied } \\
\text { Sal }\end{array}$ & $\begin{array}{c}89- \\
109\end{array}$ & $\begin{array}{c} \\
109-\end{array}$ & 95. & 94 & 94 & 4.8 \\
\hline 2. & Neutral & $68-88$ & $70-88$ & 82.3 & 83 & 83 & 5.2 \\
\hline 3. & $\begin{array}{c}\text { Dissat- } \\
\text { isfied }\end{array}$ & $47-67$ & $64-66$ & 65.2 & 65 & 65 & 0.8 \\
\hline
\end{tabular}

Data in table 5 , concluded that the mean obtained for satisfied range of score was 95.25 , median was 94 , mode was 94 and S.D was 4.8. The mean, median, mode and SD obtained for neutral range of score was $82.3,83,83$ and 5.2 respectively. The mean, median, mode and SD obtained for dis-satisfied range of score was 65.2, 65, 65 and 0.8 respectively concluding that the normal distribution and homogeneity in the level of expressed satisfaction scores. 
Table 6.Frequency and percentage distribution of the subject according to their level of expressed satisfaction related to abortion associated services in each area of service

\begin{tabular}{|c|c|c|c|c|c|c|c|c|c|c|c|}
\hline \multirow{2}{*}{$\begin{array}{l}\text { S. } \\
\text { No. }\end{array}$} & \multirow{2}{*}{$\begin{array}{c}\text { Abortion associated } \\
\text { services }\end{array}$} & \multicolumn{2}{|c|}{ Highly satisfied } & \multicolumn{2}{|c|}{ Satisfied } & \multicolumn{2}{|c|}{ Neutral } & \multicolumn{2}{|c|}{ Dissatisfied } & \multicolumn{2}{|c|}{$\begin{array}{c}\text { Highly } \\
\text { dissatisfied }\end{array}$} \\
\hline & & Freq. & (\%) & Freq. & (\%) & Freq. & (\%) & Freq. & (\%) & Freq. & (\%) \\
\hline 1. & Pre-abortion care & 8 & 0.9 & 594 & 69.7 & 129 & 15.1 & 46 & 5.3 & 75 & 8.3 \\
\hline 2. & Clinical assessment & 1 & 1 & 96 & 96 & 3 & 3 & 0 & 0 & 0 & 0 \\
\hline 3. & $\begin{array}{l}\text { During and after } \\
\text { procedure }\end{array}$ & 0 & 0 & 14 & 14 & 72 & 72 & 9 & 9 & 5 & 5 \\
\hline 4. & During hospital stay & 0 & 0 & 63 & 63 & 31 & 31 & 5 & 5 & 1 & 1 \\
\hline 5. & Post-abortion care & 1 & 1 & 26 & 26 & 34 & 34 & 7 & 7 & 32 & 32 \\
\hline 6. & Follow up & 0 & 0 & 48 & 96 & 1 & 2 & 0 & 0 & 1 & 2 \\
\hline
\end{tabular}

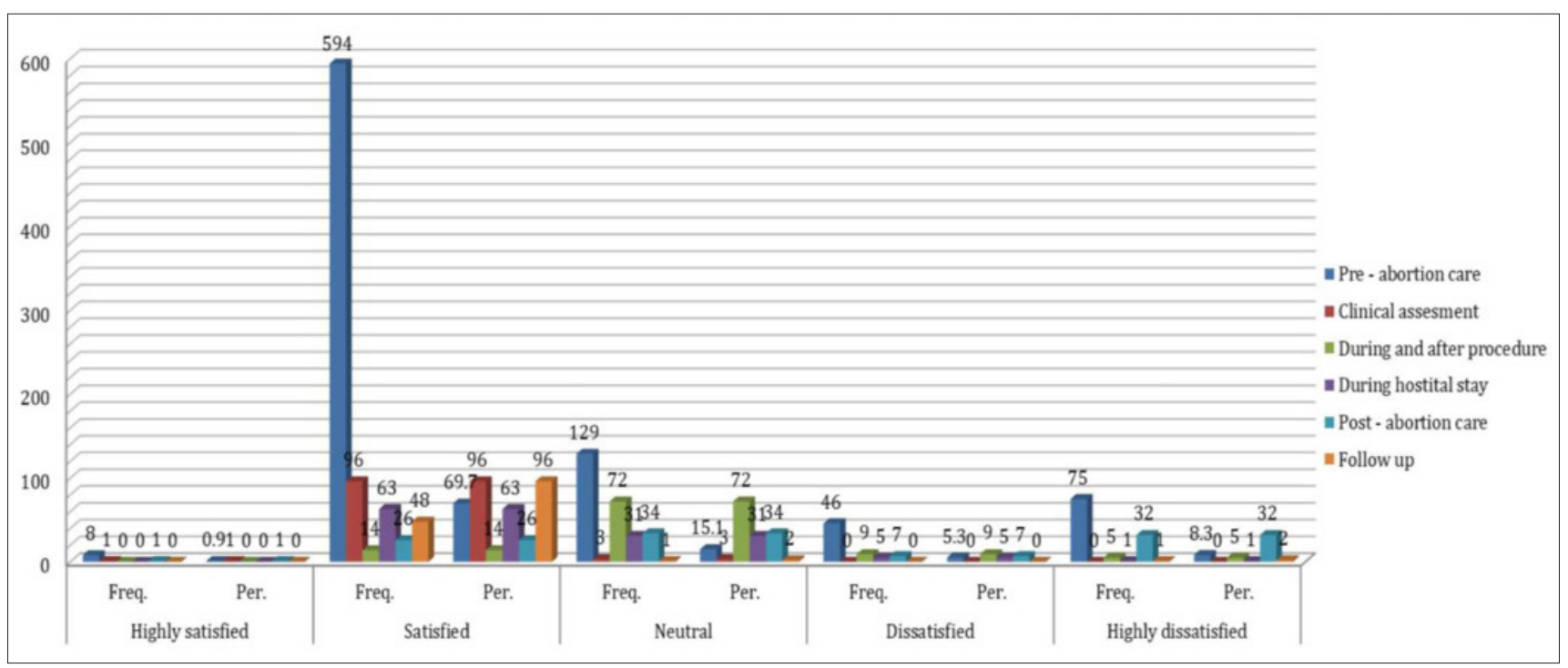

Figure 3.Bar diagram showing frequency and percentage distribution of the subject level of expressed satisfaction related to abortion associated services

Table 6 and figure 3, show that in terms of pre-abortion care, maximum number of the subjects expressed satisfaction level 594 (69.7\%) were in the satisfied range and minimum number of the subjects expressed satisfaction level 8 (0.9\%) were in the highly satisfied range, 129 (15.1\%) were in the neutral range, $46(5.3 \%)$ were in the dissatisfied range, and $75(8.3 \%)$ were in the highly dissatisfied range. In terms of clinical assessment, majority of the subject expressed satisfaction level 96 (96\%) were in the satisfied range and minimum number of the subject expressed satisfaction level $1(1 \%)$ as highly satisfied and $3(3 \%)$ were in the neutral range. During and after procedure, majority of the subjects expressed satisfaction level 72 (72\%) were in the neutral range and minimum number of the subjects expressed satisfaction level 14 (14\%), 9 (9\%), 5 (5\%) were in the satisfied, dissatisfied and highly dissatisfied range respectively. The table also show that during hospital stay, maximum number of the subjects expressed satisfaction level 63 (63\%) were in the satisfied range, and minimum number of the subjects expressed satisfaction level 31 (31\%) were in the neutral range, $5(5 \%)$ were in the dissatisfied range, $1(1 \%)$ were in the highly dissatisfied range and none of them were in the highly satisfied range. In terms of post-abortion care, almost half of the subjects expressed satisfaction level 34 (34\%) were in the neutral range, 32 (32\%) were in the highly dissatisfied range, and minimum number of the subjects expressed satisfaction level 26 (26\%) were in the satisfied range, 7 (7\%) were in the dissatisfied range and 1 (1\%) were in the highly satisfied range. During follow up, almost of the subject expressed satisfaction level 48 (96\%) were in the satisfied range, minimum number 1 $(2 \%)$ were in the neutral range and $1(2 \%)$ highly dissatisfied range and none of their expressed satisfaction level were in the highly satisfied and dissatisfied range. 
Table 7.Mean and Rank Order of various areas of abortion associated services

\begin{tabular}{|c|c|c|c|c|}
\hline S.No. & Abortion associated services & Mean & Modified mean & Rank order \\
\hline 1. & Pre- abortion care & 57.58 & 3.38 & 3 \\
\hline 2. & Clinical assessment & 7.92 & 3.96 & 1 \\
\hline 3. & During and after procedure & 5.3 & 2.60 & 5 \\
\hline 4. & During hospital stay & 6.62 & 3.31 & 4 \\
\hline 5. & Post- abortion care & 4.86 & 2.43 & 6 \\
\hline 6. & Follow up care & 3.88 & 3.88 & 2 \\
\hline
\end{tabular}

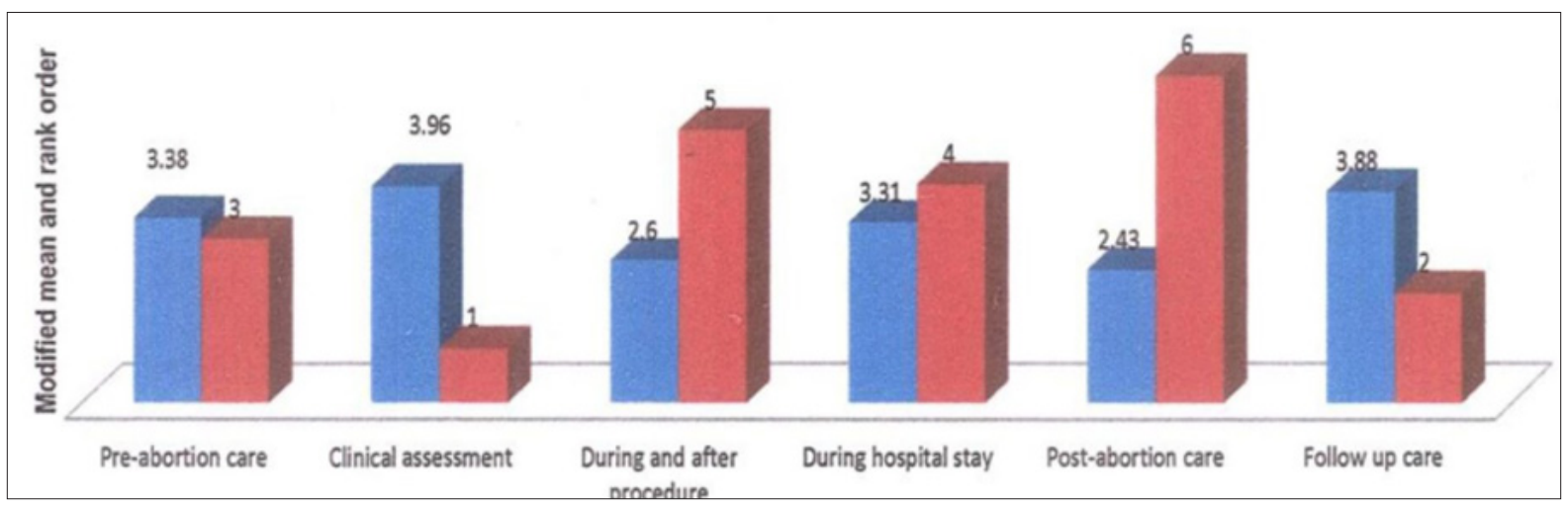

Figure 4.Bar diagram showing modified mean and rank order

The data depicted in table 7 and figure 4 , show the mean and modified mean in different areas of abortion associated services. Through modified mean, the rank order is computed. In the area of clinical assessment, the highest modified mean was observed 3.96, followed by follow up care(3.88), pre-abortion care(3.38), during hospital stay (3.31), during and after procedure (2.60),post-abortion care(2.43) respectively.

Section III: Findings Related to Association between Level of Expressed Satisfaction related to Abortion Associated Services with Selected Demographic Variables of the Woman

Table 8.Fisher Exact test to associate the level of expressed satisfaction related to abortion associated services with selected demographic variables of the woman (age, education, and occupation and community areas)

\begin{tabular}{|c|c|c|c|c|c|}
\hline $\begin{array}{c}\text { S. } \\
\text { No. }\end{array}$ & Variables & Satisfied & Neutral & $\begin{array}{c}\text { Dissa- } \\
\text { tisfied }\end{array}$ & $\begin{array}{c}\mathbf{p}- \\
\text { value }\end{array}$ \\
\hline 1. & Age in years & & & & \\
\hline & $18-24$ & 6 & 2 & 0 & 0.4 \\
\hline & $25-30$ & 11 & 8 & 4 & \\
\hline & $31-36$ & 5 & 9 & 1 & \\
\hline & $\begin{array}{c}\text { Above } 36 \\
\text { years }\end{array}$ & 2 & 2 & 0 & \\
\hline
\end{tabular}

\begin{tabular}{|c|c|c|c|c|c|}
\hline 2. & $\begin{array}{l}\text { Educational } \\
\text { level }\end{array}$ & & & & \\
\hline & Illiterate & 2 & 3 & 0 & 0.6 \\
\hline & Primary & 16 & 12 & 3 & \\
\hline & $\begin{array}{l}\text { Higher } \\
\text { secondary }\end{array}$ & 5 & 6 & 1 & \\
\hline & Graduate & 1 & 0 & 1 & \\
\hline & $\begin{array}{c}\text { Post- } \\
\text { graduate }\end{array}$ & 0 & 0 & 0 & \\
\hline 3. & Occupation & & & & \\
\hline & Housewife & 17 & 13 & 4 & 0.7 \\
\hline & Daily wager & 6 & 6 & 1 & \\
\hline & $\begin{array}{c}\text { Service( } \\
\text { govt./ } \\
\text { private) }\end{array}$ & 0 & 2 & 0 & \\
\hline & $\begin{array}{c}\text { Self- } \\
\text { employed }\end{array}$ & 1 & 0 & 0 & \\
\hline 4. & $\begin{array}{c}\text { Community } \\
\text { areas }\end{array}$ & & & & \\
\hline & Rural & 16 & 18 & 4 & 0.3 \\
\hline & Urban & 8 & 3 & 1 & \\
\hline
\end{tabular}

$\mathrm{p} \geq 0.005$, non-significant.

The data in table 8 depicts the findings of Fischer Exact test concluding no association between the levels of expressed 
satisfaction related to abortion associated services with selected demographic variables of the woman as the $p$ value obtained is $>0.005$ level of significance.

\section{Discussion}

The current study findings showed that most of the women who have undergone abortion were in the age group of 25-30 years followed by 31-36 years with educational level mostly at primary and higher secondary. Most of the subjects had conceived second time. The finding were supported by the analysis and utilization of data on 2,054 abortions from the Georgian Reproductive Health Survey and the computation of Abortion Index (AI) with the conclusion that the highest abortion rate was found in women aged 25-34 years, followed by women of aged 35-44 years and then by the youngest group. Comparing secondary educational level to university educated women, secondary educational women had higher rate of abortion. Abortion rate was found low in women with one child or less as compared to women with two to three children. It was also found that the abortion rate was highest among the poor and lowest among high income and rural women were more in the abortion group. And in terms of employment, employed women were underrepresented in the abortion group. ${ }^{8}$

In a study done in Government Hospitals of Tigray, to assess the quality and determinants of post-abortion care, only $40.6 \%$ of the clients were satisfied, $48 \%$ of the study subjects were informed about availability of family planning methods and supplied with. The study also revealed that $88.3 \%$ of the clients did not get the opportunity to pose questions or concerns. Not more than $22.2 \%$ of the care providers got refresher training on relevant areas. From the study, main concerns were identified on counseling and supporting the woman could have great input on the improvement of post-abortion care with the recommendation to skill up the providers with evidence based trainings to enhance quality of post abortion care, which is relevant to the present study findings where the subjects expressed the areas where the doctors and the nurses are lacking especially in the areas of health education and counseling regarding family planning and post abortion care. ${ }^{9}$

In a similar study done to investigate the specific factors of abortion healthcare which influence the overall satisfaction of women undergoing surgical abortion at six Northern California reproductive health clinics from two clinic systems (four clinics in System A and two clinics in System B), the top three aspects of care ranked as most important were identified from both the systems: ability to get an appointment in a timely manner, courtesy of staff and being informed as much as they wanted to know. Women were extremely fulfilled or to some degree satisfied with these highlights of considerations within both the systems with the conclusion that the factors contributing to women's satisfaction are constant. ${ }^{10}$ The study findings were also consistent with the present study findings as the study subject revealed the factors responsible for their expressed satisfaction were ability to get an appointment in a timely manner and easy accessibility of the services. It was also observed that courtesy and ability to get information depends time to time but it is most influenced by the patient ratio to doctors and nurses during a shift.

\section{Recommendation}

On the basis of the findings, the study could be replicated and for a longer time period as this would give more consistent results.

A qualitative study that throws light on various abortion stigmas can be conducted to highlight the various forms of abortion stigma and their prevalence.

An experimental study to assess the effectiveness of structured counselling clinics can also be done, which would help in setting up of special counselling clinics for the woman who have undergone abortion in order to deal with the various problems and stigma faced by them.

\section{Conclusion}

From the study, the level of expressed satisfaction of the woman related to abortion associated services was found between satisfied, neutral and dissatisfied range with the least satisfied component on post-abortion care. Emphasizing the present study findings, the researcher feels that service drawbacks can be removed with interventions on improvement of post abortion care aspect with due importance to woman's expressed satisfaction level to find out the specific factors responsible for service drawbacks.

\section{Conflict of Interest: None}

\section{References}

1. Home: Oxford English Dictionary. Available from: https://www.oed.com.

2. Susheela S, Fatima J, Elena P. Estimating abortion incidence: Assessment of widely used Indirect Method. Population Research and Policy Review 2019; 38(3): 429-458. Available from: https://www.ncbi.nlm.nih. gov>pmc.

3. SushantaK, Janardan W, Kathryn A. Woman centered research on access to safe abortion services and implications for behavioural change communication interventions: A cross-sectional study of women in Bihar and Jharkhand. BMC Public Health 2012; 12(175). Available from: https://www.researchgate.net $>2216$. DOI:10.1186/1471-2458-12-175[PubMed].

4. Billings D, Frentes Vetasquez J et.al. Comparing the quality of three models of post abortion care in public hospitals in Mexico. International Perspectives on 
Sexual and Reproductive Health 2003; 29(3):112-120. Available from: https://www.researchgate.net $>9071$. DOI:10.1363/ifpp.29.112.03 [PubMed].

5. Bekalu M, Dame A, Tamirie A. Dimensions of patient satisfaction with comprehensive abortion care in Addis Abada, Ethiopia. Reproductive Health 2016; 13(144). Available from: https://www. researchgate.net $>3114$. DOI:10.1186/812978-016-0259-0.

6. Kathryn M, David AC, Susan M. The role of clinical and process quality in achievingpatient satisfaction in hospitals. Decision Science 2004; 35(3):349-369. Available from: https://www.researchgate.net $>2301$. DOI: 10.111/j.0011-7315.2004.02570.x.

7. Philippa T. The long term psychosocial effects of abortion on women. The New Bioethics 2012; 18(2): 89-100. Available from: https://www.researchgate. net>2750. DOI:10.1179/20502877132.00000000012.

8. Ekaterine P, Babill Stray P. Who obtains abortion in Georgia and why? International Journal of Women's Health 2018; 10: 733-743. Available from: https://ncbi. nlm.nih.gov. DOI:10.2147/IJWH.SI8I228.

9. Balem D, Gessessew B, Amare A. Assessment of quality and determinant factors of post-abortion care in Governmental hospitals of Tigray, Ethiopia, 2013. Family Medicine and Medical Science Research 2014; 3(4). Available from: https://www.longdom. org>assessment. DOI: 10.417/2327-4972.1000140.

10. TillesC, Denny A, Cansino C, Creinin MD. Factors influencing women's satisfaction with surgical abortion. Contraception 2016; 93(2): 164-169. Available from: https://www.pubmed.ncbi.nlm.nih.gov. DOI:10.1016/j. contraception.2015.09.012. 